E. M. Gurbanov, D. Molazem

Department of Botany, Baku State University, Baku, Azerbaijan Astara Branch of Islamic Azad University, Astara, Iran

\title{
EFFECTS OF SALINE STRESS ON GROWTH AND CROP YIELD OF DIFFERENT MAIZE (ZEA MAYS) GENOTYPES
}

Effects of saline stress $(\mathrm{NaCl})$ on yield and vegetative characteristics of eight maize cultivars were studied. The cultivars K3615/1, S.C704, B73, S.C302, Waxy, K3546/6, K3653/2, and Zaqatala were cultivated in two plots of the Astara region: one was with normal soil and the other - with salty one. Salinization reduced the plant height, ear length, ear diameter, number of plant leaves, stem diameter, number of rows in an ear, number of grains in a row, and dry plant mass in all cultivars. Maximal ear length was observed in Zaqatala, B73, and S.C704, and the least one was detected in K3653/2. Salinization decreased crop yield of all the cultivars. Certain correlations between studied parameters were found.

$$
\text { Е. М. Гурбанов, Д. Молазем }
$$

Бакінський державний університет, Баку, Азербайджан Ісламський університет Азад, філіал Астари, Астара, Іран

\section{ВПЛИВ СОЛЬОВОГО СТРЕСУ НА РОСТ І ВРОЖАЙНІСТЬ КУКУРУДЗИ (ZEA MAYS) РІЗНИХ ГЕНОТИПІВ}

Досліджено вплив сольового стресу $(\mathrm{NaCl})$ на врожайність і вегетативні показники 8 сортів кукурудзи. Сорти K3615/1, S.C704, B73, S.C302, Waxy, K3546/6, K3653/2 та Zaqatala вирощували на двох ділянках району Астара із нормальним і засоленим грунтом. Засолення зменшує показники росту рослин, довжину та діаметр початку, кількість листків, діаметр стебла, кількість рядів у початку, кількість зернин у ряду та суху масу рослин усіх сортів. Найбілыша довжина початку спостерігалась у сортів Zaqatala, B73 та S.C704, а найменша - у K3653/2. Засолення зменшує врожайність усіх сортів. Визначено кореляцію між вивченими показниками.

Э. М. Гурбанов, Д. Молазем

Бакинский государственньий университет, Баку, Азербайджан Исламский университет Азад, филиал Астары, Астара, Иран

\section{ВЛИЯНИЕ СОЛЕВОГО СТРЕССА НА РОСТ И УРОЖАЙНОСТЬ КУКУРУЗЫ (ZEA MAYS) РАЗЛИЧНЫХ ГЕНОТИПОВ}

Исследовано влияние солевого стресса $(\mathrm{NaCl})$ на урожайность и вегетативные показатели 8 сортов кукурузы. Сорта K3615/1, S.C704, В73, S.C302, Waxy, K3546/6, K3653/2 и Zaqatala выращивали на двух участках района Астара с нормальной и засоленной почвой. Засоление уменьшает показатели роста растений, длины и диаметра початка, количества листьев, диаметра стебля, количества рядов в початке, количества зерен в ряду и сухой массы растений у всех сортов. Наибольшая длина початка наблюдалась у сортов Zaqatala, B73 и S.C704, а наименьшая - у K3653/2. Засоление уменьшает урожайность всех сортов. Определена корреляция между изученными показателями.

(C) E. M. Gurbanov, D. Molazem, 2009 


\section{Introduction}

Saltiness is one of the restrictive environmental factors for producing agricultural crops that highly causes decrease in agricultural products. From among the whole lands of the world about 100 million hectares $(5 \%)$ have high salinity of soil that influences the plant producing and growth $[5 ; 6]$. Producing the agricultural crops in dry and semi-dry regions of the world is quite low. This is due to the accumulation of salt in the soil $[1 ; 11]$. Saltiness causes the adverse effects on plant growth that can be provoked by the high osmotic pressure of soil solution (osmotic stress), and especially ionic effects (salt stress), nutritional imbalance or combination of these two factors $[2 ; 10]$. All the above mentioned factors cause particular negative effect on plant growth and development of biochemical and physiological processes $[1 ; 12]$.

\section{Materials and Methods}

The effects of salinization on growth and yield characteristics of maize were studied in Iran and Azerbaijan in 2007-2008. Seeds of 8 maize cultivars including K3615/1, S.CDS704, B73, S.C302, Waxy, K3546/6, K3653/2, and Zaqatala were cultivated on two plots in Astara: one plot had normal soil but the other one - salty soil. The experiment was carried out as a randomized complete block design made by three replications. During the experiment, characteristics of the plant growth, such as plant height, leaf numbers, leaf relative water content (LRWC), stem diameter and dry mass of the single plant as well as yield characteristics such as the ear length, ear diameter, number of rows in the ear, weight of 100 grains and crop yield per hectare, were measured.

Leaf relative water content (LRWC) was calculated on the basis of Yamasaki \& Dillenburg method [15]. Two leaves were randomly chosen from middle part of a plant for each replication. At first, leaves were separated from the stems and their fresh mass (FM) were calculated. In order to measure the turgid mass (TM), they were placed in the distilled water into closed containers for 24 hours under $22^{\circ} \mathrm{C}$. Being reached the biggest turgid mass the leaves were weighed. Then leaves were placed inside the electrical oven for 48 hours under the $80^{\circ} \mathrm{C}$ and the dry mass of the leaves (DM) were calculated. All the weightings were done with the scales of $0.001 \mathrm{~g}$ accuracy. The LRWC was calculated according to the following formula:

$$
L R W C=[(F M-D M)(T M-D M)] \times 100, \%
$$

In order to measure the plants' dry mass, they were cut as a whole. The grains, ear shanks, stems and leaves were dried at the oven at $60^{\circ} \mathrm{C}$ for 72 hours and then their dry mass was recorded. Statistical analysis was done on the basis of randomized complete block design. The Duncan's new multiple range test at the 0.05 significance level was used for statistical analysis.

\section{Results and discussion}

Data obtained from the experiment showed significant differences between cultivars regarding the most of studied characteristics. As compared to normal conditions, salinization had caused reduction in characteristics' values. The greatest LRWC was found in cultivar B73 under normal conditions and its least amount was found in S.C302 under the saltiness influence. Levent Tuna et al showed that the salinization stress entails a reduction in the LRWC capacity, plant height, stem diameter, number and weight of ear in maize [9]. There were significant differences among the cultivars in the plants' heights under the normal and salty conditions. For all the cultivars the salinization caused a decrease in the plants' height. The greatest height was for S.C704 and Zaqatala under normal conditions. In case of both normal and salty conditions, the least amount of the plants' height was seen in K3545/6 (table 1). 
Due to the salinization, leaves numbers in all the cultivars were decreased. Under normal and salty conditions, Waxy had the least leaves numbers among the cultivars and there weren't any significant differences among other cultivars under normal conditions. Salty conditions caused decrease in stem diameter in all the cultivars. The greatest stem diameter was seen in S.C704 and its least amount in Waxy under the salty conditions. In an experiment done by Hussain there was shown that saltiness reduces the plant height, leaves number, length of cob, grains number and the total grains number in the ear [8]. As compared to the normal conditions, saltiness reduced the ear length in all the cultivars. The greatest ear length was seen in Zaqatala, B73 and S.C704, and the least amount - in K3653/2. Similar results were reported by Blanco et al. They showed that salinization reduces dry masses of ear, leaves, stems and the whole plants significantly [4].

Table 1

Vegetative Characteristics of the Maize Cultivars under Normal and Salty Conditions

\begin{tabular}{|c|c|c|c|c|c|c|c|}
\hline $\begin{array}{l}\text { Condi- } \\
\text { tions }\end{array}$ & Cultivars & LRWC, \% & $\begin{array}{c}\text { Plant height, } \\
\mathrm{cm}\end{array}$ & $\begin{array}{c}\text { Leaves number, } \\
\text { unit/plant }\end{array}$ & $\begin{array}{c}\text { Stem diameter, } \\
\mathrm{mm}\end{array}$ & $\begin{array}{c}\text { Ear length, } \\
\mathrm{cm}\end{array}$ & $\begin{array}{c}\text { Ear diameter, } \\
\mathrm{mm}\end{array}$ \\
\hline $\begin{array}{l}\text { चే } \\
\text { Ẽ } \\
\text { Z }\end{array}$ & $\begin{array}{l}1-\text { Zaqatala } \\
2-\text { S.C302 } \\
3-\text { K3653.2 } \\
4-\text { B73 } \\
5-\text { S.C704 } \\
6-\text { Waxy } \\
7-\text { K3615.1 } \\
8-\text { K3545.6 }\end{array}$ & $\begin{array}{l}61.02^{\mathrm{a}} \\
57.88^{\mathrm{a}} \\
63.78^{\mathrm{a}} \\
67.15^{\mathrm{a}} \\
62.57^{\mathrm{a}} \\
61.89^{\mathrm{a}} \\
61.07^{\mathrm{a}} \\
58.43^{\mathrm{a}}\end{array}$ & $\begin{array}{l}271.0^{\mathrm{a}} \\
244.5^{\mathrm{ab}} \\
194.4^{\mathrm{def}} \\
241.5^{\mathrm{abc}} \\
279.4^{\mathrm{a}} \\
205.5^{\text {bcdef }} \\
203.5^{\text {bcdef }} \\
123.5^{\text {hi }}\end{array}$ & $\begin{array}{l}14.03^{\mathrm{a}} \\
12.70^{\mathrm{ab}} \\
13.70^{\mathrm{a}} \\
12.53^{\mathrm{abc}} \\
13.40^{\mathrm{a}} \\
10.10^{\mathrm{de}} \\
12.60^{\mathrm{abc}} \\
12.17^{\mathrm{abcd}}\end{array}$ & $\begin{array}{l}22.13^{\mathrm{abc}} \\
22.16^{\mathrm{abc}} \\
20.25^{\mathrm{abcdef}} \\
22.02^{\mathrm{abcd}} \\
23.04^{\mathrm{a}} \\
19.96^{\mathrm{abcdef}} \\
21.03^{\mathrm{abcde}} \\
22.69^{\mathrm{ab}}\end{array}$ & $\begin{array}{l}20.58^{\mathrm{a}} \\
15.27^{\mathrm{de}} \\
17.53^{\mathrm{bc}} \\
19.79^{\mathrm{a}} \\
19.03^{\mathrm{ab}} \\
15.86^{\mathrm{cde}} \\
14.24^{\mathrm{ef}} \\
16.80^{\mathrm{cd}}\end{array}$ & $\begin{array}{l}47.18^{\mathrm{a}} \\
39.97^{\mathrm{cde}} \\
41.44^{\mathrm{abcd}} \\
44.77^{\mathrm{abc}} \\
44.49^{\mathrm{abc}} \\
41.91^{\mathrm{abc}} \\
46.87^{\mathrm{ab}} \\
43.26^{\mathrm{abc}}\end{array}$ \\
\hline 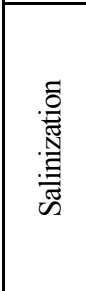 & $\begin{array}{l}1-\text { Zaqatala } \\
2-\mathrm{S} . \mathrm{C} 302 \\
3-\mathrm{K} 3653.2 \\
4-\mathrm{B} 73 \\
5-\mathrm{S} . \mathrm{C} 704 \\
6-\mathrm{Waxy} \\
7-\mathrm{K} 3615.1 \\
8-\mathrm{K} 3545.6\end{array}$ & $\begin{array}{l}61.47^{\mathrm{a}} \\
57.27^{\mathrm{a}} \\
61.70^{\mathrm{a}} \\
61.68^{\mathrm{a}} \\
62.36^{\mathrm{a}} \\
61.60^{\mathrm{a}} \\
58.44^{\mathrm{a}} \\
63.62^{\mathrm{a}}\end{array}$ & $\begin{array}{l}197.4^{\text {cdef }} \\
166.0^{\text {efgh }} \\
150.7^{\text {gh }} \\
206.9^{\text {bcde }} \\
212.0^{\text {bcd }} \\
161.3^{\text {fgh }} \\
177.6^{\text {defg }} \\
107.9^{\text {i }}\end{array}$ & $\begin{array}{c}12.52^{\mathrm{abc}} \\
11.05^{\mathrm{bcd}} \\
10.93^{\mathrm{bcd}} \\
12.10^{\mathrm{abcd}} \\
11.97^{\mathrm{abcd}} \\
8.59^{\mathrm{e}} \\
10.53^{\mathrm{cd}} \\
10.87^{\mathrm{bcd}}\end{array}$ & $\begin{array}{l}17.47^{\text {bcdefg }} \\
15.45^{\text {fg }} \\
15.87^{\text {efg }} \\
16.76^{\text {defg }} \\
17.13^{\text {cdefg }} \\
13.00^{\text {g }} \\
15.43^{\text {fg }} \\
19.31^{\text {abcdef }}\end{array}$ & $\begin{array}{l}17.74^{\mathrm{bc}} \\
10.69^{\mathrm{g}} \\
10.64^{\mathrm{g}} \\
14.06^{\mathrm{ef}} \\
14.64^{\mathrm{e}} \\
14.22^{\mathrm{ef}} \\
9.86^{\mathrm{g}} \\
12.50^{\mathrm{f}}\end{array}$ & $\begin{array}{l}43.44^{\text {abc }} \\
40.27^{\text {cde }} \\
35.02^{\mathrm{e}} \\
39.59^{\text {cde }} \\
35.58^{\text {de }} \\
39.50^{\text {cde }} \\
41.60^{\text {abcd }} \\
40.93^{\text {bcde }}\end{array}$ \\
\hline
\end{tabular}

*Within each column, the same letter indicates no significant difference between treatments $(\mathrm{p}<0.05)$

The salty condition is known to cause the decrease in water absorption by plants. For example, an experiment done for the purpose of determining the relation between water and tomato plant, showed that irrigating the plant with the salty water caused decrease of both the plant growth and the amount of absorbable water [14]. Ear diameter was also reduced due to the saltiness. Under normal conditions, the least amount of ear diameter was found in S.C302 that significantly differs from the other cultivars. The least amount of the ear diameter was seen in K3653/2 (table 1).

The greatest ear mass was found in S.C704 that didn't have any significant difference with Zaqatala and B37. Together with the investigation of vegetative growth under salty conditions, some yield parameters are also studied. The most important parameters are plant height, stem diameter, and yield characteristics of the plants [3]. Salinization caused reduction in the number of rows in an ear and the number of grains in a row (table 2). Weight of 100 grains was decreased because of the salinization. The greatest weight of 100 grains was recorded in Zaqatala cultivar and its least amount was seen in K3653.2. Dry mass of the plant was also decreased and the greatest dry mass was found in S.C704 that didn't have any significant difference with B73, K3653.2, S.C704, and K3615.1 cultivars. 
Yield Characteristics of the Maize Cultivars under Normal and Salty Conditions

\begin{tabular}{|c|c|c|c|c|c|c|}
\hline Conditions & Cultivars & Rows/ear & Grains/row & $\begin{array}{l}100 \text { grains } \\
\text { weight, } g\end{array}$ & $\begin{array}{c}\text { Dry weight, } \\
\text { g/plant }\end{array}$ & $\begin{array}{c}\text { Grain yield, } \\
\text { ton/ha }\end{array}$ \\
\hline $\begin{array}{l}\bar{\Xi} \\
\text { Z्ठ } \\
\text { Z }\end{array}$ & $\begin{array}{l}1-\text { Zaqatala } \\
2-\mathrm{S} . \mathrm{C} 302 \\
3-\mathrm{K} 3653.2 \\
4-\mathrm{B} 73 \\
5-\mathrm{S} . \mathrm{C} 704 \\
6-\text { Waxy } \\
7-\mathrm{K} 3615.1 \\
8-\mathrm{K} 3545.6\end{array}$ & $\begin{array}{l}15.79^{\text {bcdef }} \\
16.58^{\text {bcde }} \\
19.00^{\mathrm{a}} \\
15.15^{\text {defg }} \\
15.30^{\text {cdefg }} \\
14.10^{\text {fgh }} \\
15.86^{\text {bcdef }} \\
17.80^{\text {ab }}\end{array}$ & $\begin{array}{l}35.90^{\text {ab }} \\
23.31^{\text {cde }} \\
29.39^{\mathrm{c}} \\
37.07^{\mathrm{a}} \\
38.93^{\mathrm{a}} \\
29.36^{\mathrm{c}} \\
23.70^{\text {cde }} \\
30.08^{\mathrm{bc}}\end{array}$ & $\begin{array}{l}24.50^{\mathrm{a}} \\
17.85^{\mathrm{bc}} \\
15.70^{\mathrm{bc}} \\
17.95^{\mathrm{bc}} \\
15.07^{\mathrm{bc}} \\
16.43^{\mathrm{bc}} \\
16.10^{\mathrm{bc}} \\
18.93^{\mathrm{b}}\end{array}$ & $\begin{array}{l}172.67^{\text {bcde }} \\
170.74^{\text {bcde }} \\
284.29^{\text {ab }} \\
405.99^{\mathrm{a}} \\
250.85^{\text {abc }} \\
175.79^{\text {bcde }} \\
207.79^{\text {abcd }} \\
185.63^{\text {bcde }}\end{array}$ & $\begin{array}{l}4.49^{\mathrm{ab}} \\
3.70^{\mathrm{abc}} \\
3.43^{\mathrm{bcd}} \\
3.58^{\mathrm{bc}} \\
5.87^{\mathrm{a}} \\
3.07^{\mathrm{bcde}} \\
4.77^{\mathrm{ab}} \\
4.34^{\mathrm{ab}}\end{array}$ \\
\hline 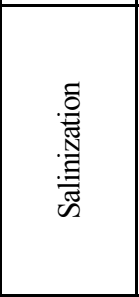 & $\begin{array}{l}1 \text { - Zaqatala } \\
2-\mathrm{S} . C 302 \\
3-\mathrm{K} 3653.2 \\
4-\mathrm{B} 73 \\
5-\mathrm{S} . \mathrm{C} 704 \\
6-\text { Waxy } \\
7-\mathrm{K} 3615.1 \\
8-\mathrm{K} 3545.6\end{array}$ & $\begin{array}{l}16.19^{\text {bcdef }} \\
17.00^{\text {abcd }} \\
15.95^{\text {bcdef }} \\
14.09^{\text {fgh }} \\
13.39^{\text {gh }} \\
12.95^{\mathrm{h}} \\
14.58^{\text {efgh }} \\
17.33^{\text {abc }}\end{array}$ & $\begin{array}{l}29.95^{\mathrm{bc}} \\
22.02^{\mathrm{de}} \\
19.29^{\mathrm{de}} \\
24.70^{\mathrm{cd}} \\
23.70^{\mathrm{cde}} \\
25.70^{\mathrm{cd}} \\
17.21^{\mathrm{e}} \\
21.61^{\mathrm{de}}\end{array}$ & $\begin{array}{l}18.43^{\mathrm{bc}} \\
14.33^{\mathrm{bc}} \\
12.90^{\mathrm{c}} \\
16.33^{\mathrm{bc}} \\
14.50^{\mathrm{bc}} \\
15.13^{\mathrm{bc}} \\
15.75^{\mathrm{bc}} \\
13.70^{\mathrm{bc}}\end{array}$ & $\begin{array}{c}104.87^{\mathrm{de}} \\
129.98^{\mathrm{bcde}} \\
86.21^{\mathrm{de}} \\
94.11^{\mathrm{de}} \\
175.35^{\mathrm{bcde}} \\
75.05^{\mathrm{e}} \\
117.99^{\mathrm{cde}} \\
74.12^{\mathrm{e}} \\
\end{array}$ & $\begin{array}{l}2.16^{\text {cdef }} \\
2.40^{\text {cdef }} \\
1.53^{\text {f }} \\
1.73^{\text {ef }} \\
2.60^{\text {cdef }} \\
1.84^{\text {def }} \\
1.24^{\text {f }} \\
1.31^{\text {f }}\end{array}$ \\
\hline
\end{tabular}

*Within each column, the same letter indicates no significant difference between treatments $(\mathrm{p}<0.05)$

Hussain et al showed that increase in saltiness level had caused decrease in maize height, stem diameter, leaves numbers, leaf areas and dry mass of the plant [7]. As compared to the normal environment, under salty conditions yield of cultivar grains was decreased. S.C704 bears the greatest grain yield and under salty conditions and K3615.1 had the least grain yield (table 2).

Correlations between the characteristics under both normal and salty conditions are presented in tables 3 and 4. Under normal conditions there was a significant and positive correlation between the plant height and ear length, and the number of grains in a row. A positive and significant correlation was seen among the stem diameter and ear diameter, and the number of grains in a row.

Table 3

Simple Correlation between Crop Yield and Some Growth Characteristics under Normal Conditions

\begin{tabular}{|c|c|c|c|c|c|c|c|c|c|c|}
\hline & 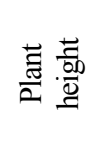 & 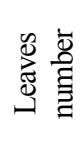 & 离 & 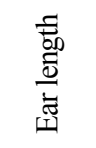 & 矛 $\frac{\grave{\Xi}}{\stackrel{\Xi}{\Xi}}$ & $\frac{\vec{d}}{\omega}$ & 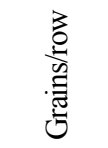 & 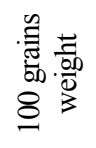 & $\begin{array}{l}\text { 름 } \\
\frac{000}{0} \\
3 \\
3 \\
0\end{array}$ & 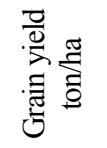 \\
\hline LRWC & -0.011 & 0.155 & -0.004 & -0.096 & -0.169 & -0.085 & 0.015 & -0.080 & -0.163 & -0.115 \\
\hline Plant height & 1 & 0.359 & 0.355 & $0.503^{*}$ & 0.396 & -0.347 & $0.50^{*}$ & 0.224 & 0.101 & 0.290 \\
\hline Leaf number & - & 1 & 0.074 & 0.328 & 0.166 & 0.293 & 0.184 & 0.226 & -0.023 & 0.311 \\
\hline Stem diameter & - & - & 1 & 0.245 & $0.458 *$ & 0.146 & $0.427 *$ & 0.169 & 0.228 & 0.396 \\
\hline Ear length & - & - & - & 1 & $0.442 *$ & -0.690 & $0.887^{* * *}$ & 0.398 & $0.413 *$ & 0.275 \\
\hline Ear diameter & - & - & - & - & 1 & -0.039 & $0.520^{* *}$ & 0.391 & 0.320 & $0.624 * *$ \\
\hline No. of rows/ear & - & - & - & - & - & 1 & -0.206 & 0.004 & 0.059 & -0.047 \\
\hline No. of grains/row & - & - & - & - & - & - & 1 & 0.265 & 0.370 & $0.438^{*}$ \\
\hline 100-grains weight & - & - & - & - & - & - & - & 1 & -0.121 & 0.176 \\
\hline Dry weight & - & - & - & - & - & - & - & - & 1 & 0.283 \\
\hline Grain yield ton/ha & - & - & - & - & - & - & - & - & - & 1 \\
\hline
\end{tabular}

* Significant difference at the 0.05 significance level; ** significant difference at the 0.01 significance level. 
Simple Correlation between Crop Yield and Some Growth Characteristics under Salty Conditions

\begin{tabular}{|c|c|c|c|c|c|c|c|c|c|c|}
\hline & 䓂 & 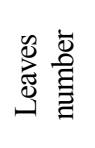 & 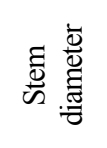 & 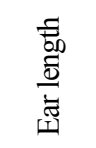 & 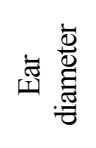 & $\frac{\vec{\Xi}}{\tilde{D}}$ & 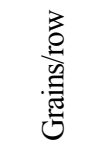 & 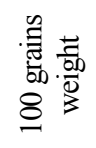 & 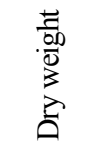 & 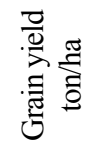 \\
\hline LRWC & -0.154 & 0.053 & $0.539 * *$ & 0.404 & 0.121 & 0.006 & 0.232 & -0.089 & 0.127 & 0.266 \\
\hline Plant height & 1 & 0.359 & -0.058 & $0.445^{*}$ & -0.018 & -0.269 & 0.348 & 0.192 & 0.377 & 0.202 \\
\hline Leaf number & - & 1 & 0.312 & 0.312 & 0.214 & 0.318 & 0.173 & 0.087 & 0.151 & 0.179 \\
\hline Stem diameter & - & - & 1 & 0.310 & 0.077 & 0.345 & 0.216 & 0.096 & 0.155 & -0.038 \\
\hline Ear length & - & - & - & 1 & 0.335 & -0.067 & $0.889^{* *}$ & 0.167 & 0.121 & $0.404 *$ \\
\hline Ear diameter & - & - & - & - & 1 & $0.440 *$ & $0.439^{*}$ & 0.396 & -0.121 & 0.232 \\
\hline No. of rows/ear & - & - & - & - & - & 1 & 0.102 & -0.085 & 0.002 & 0.130 \\
\hline No. of grains/row & - & - & - & - & - & - & 1 & 0.189 & 0.008 & $0.465^{*}$ \\
\hline 100-grainWeight & - & - & - & - & - & - & - & 1 & 0.154 & 0.199 \\
\hline Dry weight & - & - & - & - & - & - & - & - & 1 & 0.383 \\
\hline Grain yield ton/ha & - & - & - & - & - & - & - & - & - & 1 \\
\hline
\end{tabular}

* Significant difference at the 0.05 significance level; ** significant difference at the 0.01 significance level.

There was a significant and positive correlation among the ear length and ear diameter, the number of grains in a row and dry mass of the plant. A positive correlation was recorded among the ear diameter and the number of grains in a row and grain yield. A positive and significant correlation was also obtained among the number of grains in a row with the grain yield. Under salty conditions there was also a significant and positive correlation between the plant height and ear length. A significant difference was found between the number of grains in a row with grain yield and ear diameter with the number of rows in an ear and the number of grains in a row.

\section{References}

1. Evaluation of arid and semi-arid ecotypes of guar (Cyamopsis tetragonoloba L.) for salinity ( $\mathrm{NaCl}$ ) tolerance / M. Y. Ashraf, K. Akhtar, G. Sarwar, M. Ashraf // Journal of Arid Environment. - 2002. Vol. 52. - P. 437-482.

2. Ashraf M. Some important physiological selection criteria for salt tolerance in plants // Flora Review. 2004. - Vol. 199. - P. 361-376.

3. Blumwold E. Sodium transport and salt tolerance in plants // Current Opinion in Cell Biology. 2000. - Vol. 12. - P. 431-434.

4. Growth and yield of corn irrigated with saline water / F. Blanco, M. V. Folegatti, H. R. Gheyi, P. D. Fernandes // Sci. Agric. (Piracicaba, Braz.). - 2008. - Vol. 65, N 6. - P. 574-580.

5. Ghassemi F. Salinisation of land and water resources / F. Ghassemi, A. J. Jakeman, H. A. Nix. Wallingford, UK: CAB International, 1995.

6. Salicylic acid induced changes on some physiological parameters symptomatic for oxidative stress and mineral nutrition in maize (Zea mays L.) grown under salinity / A. Gunes, A. Inal, M. Alpaslan et al. // Journal of Plant Physiology. - 2007. - Vol. 164, N 6. - P. 728-736.

7. Hussain M. Salicylic acid and salinity effects on growth of maize plants / M. Hussain, L. K. Balbaa, M. S. Goballah // Research Journal of Agriculture and Biological Sciences. - 2007. - N 3 (4). P. 321-328.

8. Hussain M. Effect of salinity on germination, growth and some chemical constituents of maize (Zea mays L.) // Pakistan Agriculture database. - 2001. - Record N601.

9. Comparative effects of various salicylic acid derivatives on key growth parameters and some enzyme activities in salinity stressed maize (Zea mays L.) plants / T. A. Levent, C. Kaya, M. Dikilitas et al. // Pak. J. Bot. - 2007. - Vol. 39, N 3. - P. 787-798. 
10. Marschner H. Mineral nutrition of higher plants. - London: Acad. Pr., 1995.

11. Munns R. Comparative physiology of salt and water stress // Plant Cell Environ. - 2002. - Vol. 25. P. 239-250.

12. Munns R. Screening methods for salinity tolerance: a case study with tetraploid wheat / R. Munns, R. A. James // Plant Soil. - 2003. - Vol. 253. - P. 201-218.

13. Pesserakli M. Dry matter, yield, nitrogen absorption, and water uptake by sweet corn under salt stress / M. Pesserakli, J. T. Huber // J. Plant Nutr. - 1987. - Vol. 12. - P. 279-290.

14. Romero-Aranda R. Tomato plant water uptake and plant water relationships under saline growth conditions / R. Romero-Aranda, T. Soria, J. Cuartero // Plant Sci. - 2001. - Vol. 160. - P. 265-272.

15. Yamasaki S. Measurements of leaf relative water content in Araucaria angustifolia / S. Yamasaki, L. C. Dillenburg // R. Bras. Fisiol. - 1999. - Veg. 11. - P. 69-75.

Надійшла до редколегї 20.05.2009 